\title{
EFFECT OF DIETARY ENERGY AND CORN GLUTEN FEED ON THE PERFORMANCE OF GROWING WHITE PEKIN DUCKS.
}

\section{I.I. Hassan}

Animal Production Research Institute, Agricultural Research Center, Dokki, Giza, Egypt.

\section{ABSTRACT:}

A factorial design experiment (3x3) was performed to study the effect of three levels of energy (2800, 3000 and $3200 \mathrm{Kcal} \mathrm{ME/Kg}$ ) and three levels of corn gluten feed, CGF (0, 8 and 16\%) on growth performance and economical efficiency of White Pekin ducklings.

A total number of 270 unsexed two-weeks-old White Pekin ducklings were randomly distributed among 9 treatment groups (30 ducklings each) nearly equal in average live body weight. Each group was subdivided into three replicates each of 10 ducklings. Growth performance, some carcass traits, blood constituents and economical efficiency were studied. The results obtained could be summarized as follows:

Live body weight and daily weight gain were significantly $(P<0.05)$ higher with the $3000 \mathrm{Kcal} \mathrm{ME/Kg}$ diet energy level at most experimental period. During the starter ( 2 to 7 weeks age) and the whole experimental (2 to 12 weeks age) periods, improved $(P<0.05)$ feed conversion values were noticed with the $3000 \mathrm{Kcal} \mathrm{ME} / \mathrm{Kg}$ diet energy level. Ducklings fed the level of $8 \%$ corn gluten feed possessed significantly $(P<0.05)$ higher live body weight at 7 and 12 weeks of age than those fed 0 or $16 \%$ corn gluten feed. The best feed conversion value was found with ducklings fed 8\% CGF. Liver, heart, total giblets and abdominal fat percentages were significantly $(P<0.05)$ affected by dietary energy level. The previous carcass traits increased with increasing dietary energy level in Pekin duckling diets. However, no significant effects of dietary energy level on gizzard, carcass and dressing weight percentages of Pekin ducklings were observed. It is worth to note that, liver, heart, carcass and dressing percentages were increased significantly $(P<0.05)$ with the increasing the dietary corn gluten feed from 0 to $16 \%$.Increasing the dietary energy level from 2800 to either 3000 or $3200 \mathrm{Kcal} \mathrm{ME/Kg}$ diet caused a significant $(P<0.05)$ increase in cholesterol blood values. Ducklings fed the diet 
contained $3000 \mathrm{Kcal} \mathrm{ME/Kg}$ diet and 8\% CGF recorded the best EEf as compared with other treatment or control.

From the previous results, it can be concluded that a dietary level of $3000 \mathrm{Kcal} \mathrm{ME} / \mathrm{Kg}$ diet with $8 \%$ CGF is recommended for feeding growing Pekin ducks from 2 to 12 weeks of age.

Keywords: Dietary energy, corn gluten feed, performance, Pekin ducks.

\section{INTRODUCTION}

In poultry diets, dietary energy-contributing ingredients' are major cost and optimal energy level is important for lowering feed cost per unit of poultry product. Recently, many studies were conducted to examine the effects of the dietary energy on the growth of broiler chickens. Increasing dietary energy level caused improve feed conversion rate of broilers by reducing feed intake (Dozier et al., 2007 and Ghaffari et al., 2007). However, high dietary energy caused deposition of excess abdominal fat or carcass fat in broilers (Ghaffari et al., 2007) and the abdominal fat was usually considered as a waste product when birds were processed further, which indicated the economic loss for poultry producers.

Yellow corn is one of the richest sources of dietary energy in poultry feeding. According to the published statistics, corn forms the greatest share in Egyptian imported feedstuffs owing to its use in producing certain products for human, animal and poultry intake. Accordingly, there is an urgent need to search for alternative feedstuffs or by-products, which could be used as cheap sources of energy to replace yellow corn grains in the formulated poultry diets.

The production of corn gluten feed (CGF) in Egypt, a co-product of the wet milling industry has been steadily increased during the last years. The incorporation of CGF at $7.5 \%$ in turkey breeder diets improved the productive and reproductive performance (Hillman et al., 1973). El-Deek et al. (2009) indicated that CGF could be incorporated successively up to $20 \%$ in commercial laying hens diets without adversely affecting productive performance and economical efficiency.

It is well known that ducks are characterized with their high resistant to diseases, high voluntary feed intake and could tolerate high fiber content in their rations.

Therefore, the present study aimed to show some light on the effect of dietary energy and corn gluten feed on the performance of growing while Pekin ducklings, under Egyptian environmental conditions. 


\section{MATERIALS AND METHODS}

The experimental work of this study was carried out at the Poultry Research Farm, Faculty of Agriculture, Zagazig University, Egypt.

A (3x3) factorial design experiment was performed to study the effect of three levels of energy $(2800,3000$ and $3200 \mathrm{Kcal} \mathrm{ME} / \mathrm{Kg}$ diet) and three levels of corn gluten feed, CGF (0, 8 and 16\%) on growth performance and economical efficiency of White Pekin ducklings during the experimental period from 2 to 12 weeks of age.

A total number of 270 unsexed two-week-old White Pekin ducklings were randomly distributed among 9 treatment groups ( 30 ducklings each) nearly equal in average live body weight. Each group was subdivided into three replicates each of 10 ducklings. Three experimental basal diets were formulated to contain 2800, 3000 and $3200 \mathrm{Kcal} \mathrm{ME} / \mathrm{Kg}$ diet. Within each dietary energy level, corn gluten feed (CGF) was incorporated at levels 0 (control), 8 and $16 \%$ in the starter (from 2 to 7 weeks of age) and finisher (from 7 to 12 weeks of age) mash diets. Composition and calculated analysis of the experimental mash diets are presented in Tables 1 and 2. All experimental diets were isonitrogenous. Ducklings were reared on floor under similar environmental conditions throughout the experimental periods. Feed and water were allowed all the time.

Individual body weights of ducklings were recorded at 2, 7 and 12 weeks of age, and body weight gain was calculated. Feed intake data was recorded weekly on a replicate basis during the experimental periods. Consequently, feed conversion (g feed/g gain) was estimated.

At 12 weeks of age, three birds from each treatment were randomly taken, deprived from feed, but water was allowed, for about 12 hours, weighed, slaughtered to complete bleeding, followed by plucking the feathers then reweighed. The carcass traits studied were giblets (gizzard, liver and heart) abdominal fat, carcass and dressing weight/100 g body weight. At slaughter time, twenty $\mathrm{ml}$ of blood were taken from each slaughted bird for biochemical charactersting of blood.

Serum was harvested after centrifugation of the clotted blood, stored at $-20^{\circ} \dot{\mathrm{C}}$ in the deep freezer until the time of chemical determinations. The biochemical characteristics of blood were determined calorimetrically, using commercial kits as described by Emam (2007). Serum total protein and albumin were determined calorimetrically according to Reinhold (1953) and Henry (1974), respectively. Transaminase enzyme activities (AST and ALT) were determined 
Table 1: Composition and calculated analysis of the starter diet fed to White Pekin ducklings during the experimental period from 2 to 7 weeks of age.

\begin{tabular}{|c|c|c|c|c|c|c|c|c|c|}
\hline \multirow[b]{2}{*}{ Items } & \multicolumn{3}{|c|}{$2800 \mathrm{Kcal} / \mathrm{Kg}$} & \multicolumn{3}{|c|}{$3000 \mathrm{Kcal} / \mathrm{Kg}$} & \multicolumn{3}{|c|}{$3200 \mathrm{Kcal} / \mathrm{Kg}$} \\
\hline & $\begin{array}{c}0 \% \\
\text { CGF }^{1}\end{array}$ & $\begin{array}{l}8 \% \\
\text { CGF }\end{array}$ & $\begin{array}{l}16 \% \\
\text { CGF }\end{array}$ & $\begin{array}{l}0 \% \\
\text { CGF }\end{array}$ & $\begin{array}{l}8 \% \\
\text { CGF }\end{array}$ & $\begin{array}{l}16 \% \\
\text { CGF }\end{array}$ & $\begin{array}{l}0 \% \\
\text { CGF }\end{array}$ & $\begin{array}{l}\mathbf{8 \%} \\
\text { CGF }\end{array}$ & $\begin{array}{l}16 \% \\
\text { CGF }\end{array}$ \\
\hline Yellow Corn. & 66.50 & 66.30 & 64.39 & 65.20 & 66.81 & 59.35 & 64.10 & 61.96 & 53.74 \\
\hline Soybean, $44 \%$. & 20.20 & 19.65 & 16.33 & 21.20 & 19.77 & 17.32 & 22.60 & 20.70 & 18.20 \\
\hline Corn Gluten Feed, $21 \%$. & 0.00 & 8.00 & 16.00 & 0.00 & 8.00 & 16.00 & 0.00 & 8.00 & 16.00 \\
\hline Wheat bran. & 9.60 & 0.50 & 0.00 & 7.42 & 0.00 & 0.00 & 4.20 & 0.00 & 0.70 \\
\hline Cotton seed oil. & 0.00 & 0.00 & 0.00 & 2.95 & 2.18 & 4.04 & 5.75 & 6.10 & 8.09 \\
\hline Di-calcium phosphate. & 2.60 & 2.60 & 2.60 & 2.60 & 2.60 & 2.60 & 2.60 & 2.60 & 2.60 \\
\hline DL-Methionine, $99 \%$. & 0.03 & 0.04 & 0.08 & 0.03 & 0.04 & 0.09 & 0.03 & 0.04 & 0.07 \\
\hline L-Lysine HCL, $98 \%$. & 0.00 & 0.00 & 0.00 & 0.00 & 0.00 & 0.00 & 0.00 & 0.00 & 0.00 \\
\hline Sand. & 0.47 & 2.31 & 0.00 & 0.00 & 0.00 & 0.00 & 0.12 & 0.00 & 0.00 \\
\hline Salt $(\mathrm{NaCl})$. & 0.30 & 0.30 & 0.30 & 0.30 & 0.30 & 0.30 & 0.30 & 0.30 & 0.30 \\
\hline Vit. Min. premix ${ }^{2}$ & 0.30 & 0.30 & 0.30 & 0.30 & 0.30 & 0.30 & 0.30 & 0.30 & 0.30 \\
\hline Total & 100.00 & 100.00 & 100.00 & 100.00 & 100.00 & 100.00 & 100.00 & 100.00 & 100.00 \\
\hline \multicolumn{10}{|l|}{ Calculated analysis, ${ }^{3} \%:-$} \\
\hline Crude protein., & 16.07 & 16.06 & 16.07 & 16.05 & 16.08 & 16.08 & 16.07 & 16.08 & 16.09 \\
\hline $\mathrm{ME}, \mathrm{Kcal} / \mathrm{Kg}$. & 2804 & 2807 & 2804 & 3011 & 3010 & 3009 & 3207 & 3209 & 3202 \\
\hline Crude fiber. & 3.93 & 3.53 & 3.84 & 3.73 & 3.49 & 3.80 & 3.45 & 3.45 & 3.81 \\
\hline Ether extract. & 3.07 & 2.90 & 2.98 & 2.94 & 2.90 & 2.79 & 2.78 & 2.72 & 2.62 \\
\hline Ash. & 2.82 & 2.24 & 1.96 & 2.74 & 2.22 & 1.96 & 2.62 & 2.21 & 1.98 \\
\hline Calcium. & 0.66 & 0.67 & 0.70 & 0.66 & 0.67 & 0.70 & 0.66 & 0.68 & 0.70 \\
\hline Available phosphorus. & 0.61 & 0.59 & 0.58 & 0.61 & 0.59 & 0.58 & 0.61 & 0.59 & 0.58 \\
\hline Lysine. & 0.77 & 0.74 & 0.69 & 0.77 & 0.74 & 0.71 & 0.79 & 0.76 & 0.72 \\
\hline Methionine. & 0.30 & 0.28 & 0.30 & 0.30 & 0.28 & 0.30 & 0.30 & 0.28 & 0.28 \\
\hline Met+Cys. & 0.59 & 0.54 & 0.52 & 0.59 & 0.54 & 0.53 & 0.58 & 0.53 & 0.50 \\
\hline Price / Ton diet (LE) & 1686.20 & 1699.35 & 1725.27 & 1768.88 & 1780.43 & 1816.83 & 1846.95 & \multicolumn{2}{|c|}{1867.201899 .60} \\
\hline \multicolumn{10}{|c|}{$\begin{array}{l}{ }^{1} \text { CGF }=\text { Corn gluten feed }{ }^{2} \text { Vitamin and mineral premix at } 0.3 \% \text { of the diet supplies the } \\
\text { following per kg of the diet: Vit A } 12000 \mathrm{IU} \text {, Vit } \mathrm{D}_{3} 2000 \mathrm{IU} \text {, Vit. E } 40 \mathrm{mg} \text {, Vit K3 } 4 \mathrm{mg} \text {, Vit B1 } 3 \\
\mathrm{mg} \text {, Vit B2 } 6 \mathrm{mg} \text {, Vit B6 } 4 \mathrm{mg} \text {, Vit B12 } 0.3 \mathrm{mg} \text {, Niacin } 30 \mathrm{mg} \text {, Panthothenic acid } 12 \mathrm{mg} \text {, Folic acid } \\
1.5 \mathrm{mg} \text {, Biotin } 0.08 \mathrm{mg} \text {, Choline chloride } 50 \% 700 \mathrm{mg}, \mathrm{Mn} 100 \mathrm{mg}, \mathrm{Cu} 10 \mathrm{mg}, \mathrm{Fe} 40 \mathrm{mg} \text {, Zn } 70 \\
\mathrm{mg} \text {, Se } 0.3 \mathrm{mg} \text {, I } 1.5 \mathrm{mg} \text {, Co } 0.25 \mathrm{mg} \text {, CaCO3 added at } 3000 \mathrm{~g} \text {. } \\
\text { Calculated according to NRC (1994). }\end{array}$} \\
\hline
\end{tabular}


Table 2: Composition and calculated analysis of the finisher diet fed to White Pekin ducklings during the experimental from 7 to 12 weeks of age.

\begin{tabular}{|c|c|c|c|c|c|c|c|c|c|}
\hline \multirow[b]{2}{*}{ Items } & \multicolumn{3}{|c|}{$2800 \mathrm{Kcal} / \mathrm{Kg}$} & \multicolumn{3}{|c|}{$3000 \mathrm{Kcal} / \mathrm{Kg}$} & \multicolumn{3}{|c|}{$3200 \mathrm{Kcal} / \mathrm{Kg}$} \\
\hline & $\begin{array}{l}0 \% \\
\text { CGF }^{1}\end{array}$ & $\begin{array}{l}8 \% \\
\text { CGF }\end{array}$ & $\begin{array}{l}16 \% \\
\text { CGF }\end{array}$ & $\begin{array}{l}0 \% \\
\text { CGF }\end{array}$ & $\begin{array}{l}8 \% \\
\text { CGF }\end{array}$ & $\begin{array}{l}16 \% \\
\text { CGF }\end{array}$ & $\begin{array}{l}0 \% \\
\text { CGF }\end{array}$ & $\begin{array}{l}8 \% \\
\text { CGF }\end{array}$ & $\begin{array}{l}16 \% \\
\text { CGF }\end{array}$ \\
\hline Yellow corn. & 68.80 & 68.02 & 66.40 & 67.20 & 71.00 & 63.75 & 65.40 & 66.10 & 58.80 \\
\hline $\begin{array}{l}\text { Soybean,44 } \\
\% .\end{array}$ & 17.10 & 15.90 & 13.50 & 18.10 & 16.40 & 13.90 & 19.20 & 17.45 & 14.90 \\
\hline CGF & 0.00 & 8.00 & 16.00 & 0.00 & 8.00 & 16.00 & 0.00 & 8.00 & 16.00 \\
\hline Wheat bran. & 10.60 & 3.20 & 0.00 & 8.55 & 0.00 & 0.00 & 6.47 & 0.00 & 0.00 \\
\hline $\begin{array}{l}\text { Cotton seed } \\
\text { oil. }\end{array}$ & 0.00 & 0.00 & 0.00 & 3.00 & 1.41 & 3.10 & 5.80 & 5.28 & 7.09 \\
\hline $\begin{array}{l}\text { Di-calcium } \\
\text { phosphate. }\end{array}$ & 2.50 & 2.50 & 2.50 & 2.50 & 2.50 & 2.50 & 2.50 & 2.50 & 2.50 \\
\hline $\begin{array}{l}\text { DL-Methioni } \\
99 \% .\end{array}$ & 0.02 & 0.05 & 0.08 & 0.04 & 0.05 & 0.08 & 0.03 & 0.05 & 0.08 \\
\hline $\begin{array}{l}\text { L-Lysine } \\
\text { HCL, } 98 \% \text {. }\end{array}$ & 0.00 & 0.03 & 0.06 & 0.01 & 0.04 & 0.07 & 0.00 & 0.02 & 0.03 \\
\hline Sand. & 0.38 & 1.70 & 0.86 & 0.00 & 0.00 & 0.00 & 0.00 & 0.00 & 0.00 \\
\hline Salt $(\mathrm{NaCl})$ & 0.30 & 0.30 & 0.30 & 0.30 & 0.30 & 0.30 & 0.30 & 0.30 & 0.30 \\
\hline $\begin{array}{l}\text { Vit. Min. } \\
\text { premix }^{2} \text {. }\end{array}$ & 0.30 & 0.30 & 0.30 & 0.30 & 0.30 & 0.30 & 0.30 & 0.30 & 0.30 \\
\hline Total & 100.00 & 100.00 & 100.00 & 100.00 & 100.00 & 100.00 & 100.00 & 100.00 & 100.00 \\
\hline \multicolumn{10}{|c|}{ Calculated analysis, ${ }^{3} \%:-$} \\
\hline $\mathrm{CP}$ & 15.05 & 15.03 & 15.06 & 15.05 & 15.01 & 15.02 & 15.04 & 15.03 & 15.00 \\
\hline ME,Kcal/Kg. & 2825 & 2818 & 2811 & 3029 & 3011 & 3001 & 3209 & 3206 & 3203 \\
\hline $\mathrm{CF}$ & 3.88 & 3.60 & 3.69 & 3.69 & 3.35 & 3.66 & 3.49 & 3.32 & 3.62 \\
\hline EE. & 3.18 & 3.04 & 3.03 & 3.04 & 3.03 & 2.93 & 2.90 & 2.85 & 2.75 \\
\hline Ash. & 2.71 & 2.18 & 1.81 & 2.63 & 2.06 & 1.80 & 2.55 & 2.06 & 1.79 \\
\hline Calcium. & 0.63 & 0.65 & 0.67 & 0.63 & 0.64 & 0.67 & 0.63 & 0.65 & 0.67 \\
\hline Available P & 0.59 & 0.57 & 0.56 & 0.59 & 0.57 & 0.56 & 0.58 & 0.57 & 0.55 \\
\hline Lysine. & 0.69 & 0.69 & 0.68 & 0.71 & 0.70 & 0.70 & 0.72 & 0.70 & 0.67 \\
\hline Methionine. & 0.28 & 0.28 & 0.28 & 0.29 & 0.28 & 0.28 & 0.28 & 0.28 & 0.28 \\
\hline Met+Cys. & 0.56 & 0.52 & 0.49 & 0.57 & 0.52 & 0.49 & 0.56 & 0.51 & 0.48 \\
\hline $\begin{array}{l}\text { Price / Ton } \\
\text { diet (LE) }\end{array}$ & 1654.80 & 1673.20 & 1698.50 & 1742.23 & 1744.45 & 1778.85 & 1811.71 & 1827.60 & 1860.25 \\
\hline
\end{tabular}


calorimetrically using available commercial kits produced by Bio-Meraux, France. The globulin values were obtained by subtracting the values of albumin from the corresponding values of total protein (Coles, 1974).

The economical efficiency (EEf) of experimental diets was estimated depending upon feeding cost and price of body weight during the experimental periods.

Data were statistically analyzed according to ANOVA procedures of SAS (SAS Institute, 1999). Means differences were compared using Duncan's multiple range test (Duncan, 1955).

\section{RESULTS AND DISCUSSION}

\section{Growth Performance:}

The main effects of energy and corn gluten feed levels on growth performance of White Pekin ducklings during the different experimental periods from 2-12 weeks of age are presented in Tables 3 and 4.

\section{Live body weight and weight gain: \\ Effect of energy level:}

At 7 and 12 weeks of age, the different energy levels studied showed significant effect $(\mathrm{P}<0.05$ or $\mathrm{P}<0.01)$ on live body weight of ducklings. Ducklings received $3000 \mathrm{Kcal} \mathrm{ME} / \mathrm{Kg}$ diet had higher $(\mathrm{P}<0.05)$ body weights when compared with those received either 2800 or $3200 \mathrm{Kcal} \mathrm{ME} / \mathrm{Kg}$ diet (Table 3).

The average weight gain of ducklings followed nearly the same trend observed with live body weight. Weight gain of ducklings was significantly $(\mathrm{P}<0.05)$ higher with the $3000 \mathrm{Kcal} \mathrm{ME} / \mathrm{Kg}$ diet energy level as compared to 2800 and $3200 \mathrm{Kcal} \mathrm{ME} / \mathrm{Kg}$ diet levels during 2 to 7 weeks of age (starter period), while it was significant $(\mathrm{P}<0.05)$ when compared with the $3200 \mathrm{Kcal}$ $\mathrm{ME} / \mathrm{Kg}$ diet energy level during 2 to 12 weeks of age (whole experimental period).

\section{Effect of corn gluten feed:}

The data showed that the ducklings fed the level of $8 \%$ corn gluten feed possessed significantly $(\mathrm{P}<0.05)$ higher live body weight than those fed either 0 or $16 \% \mathrm{CGF}$ at 7 weeks of age, and only significant for those fed $8 \%$ CGF compared with those fed $16 \%$ CGF at 12 weeks of age. Similar results were 
I. HASSAN 
observed for weight gain, during 2 to 7 and 2 to 12 weeks of age. However, weight gain was not significantly affected by dietary CGF\% during 7 to 12 weeks of age (Table 3).

\section{Feed intake and feed conversion Effect of energy level:}

Results of the present study showed that feed intake significantly $(\mathrm{P}<0.05)$ decreased as dietary energy level increased from 2800 to either 3000 or 3200 $\mathrm{Kcal} \mathrm{ME} / \mathrm{Kg}$ diet during the all experimental periods (Table 4). The low energy feed was responsible for any increase in feed intake during the starter and finisher periods. This may be explained on the basis that ducklings required more dietary energy values covered by increasing feed intake to certain extent.

Data in Table 4 showed that feed conversion values were improved $(\mathrm{P}<0.05)$ with increasing the dietary energy level from 2800 to either 3000 or $3200 \mathrm{Kcal} \mathrm{ME} / \mathrm{Kg}$ diet during the starter ( 2 to 7 weeks age) and the whole experimental ( 2 to 12 weeks age) periods. While, energy level had no significant effect on feed conversion ratio during the finisher period (7 to 12 week age). Improvement in feed conversion ratio of ducklings appears to be due to higher growth rate caused by the $3000 \mathrm{Kcal} \mathrm{ME} / \mathrm{Kg}$ diet energy level.

\section{Effect of corn gluten feed:}

Dietary CGF at different levels had no significant effect on feed intake of ducklings, during all the experimental periods (Table 4).

Results of feed conversion ratio showed no significant differences among various treatments due to CGF level effects during 2 to 7 and 7 to 12 weeks of age, while it was significantly $(\mathrm{P}<0.05)$ affected during 2 to 12 weeks of age (Table 4). The best feed conversion value was recorded with ducklings fed CGF at the level of $8 \%$, which may be due to the higher growth rate at this level, while the poorest value was observed for those fed the diet with 16\% CGF.

\section{Interaction effects:}

The interaction effects between dietary energy and CGF levels on all growth performance traits studied were significant $(\mathrm{P}<0.05$ or $\mathrm{P}<0.01)$, except for weight gain and feed conversion during 7 to 12 weeks of age (Tables 3 and 4). When taking live body weight and body weight gain into consideration, it could be concluded that the level of $3000 \mathrm{Kcal} \mathrm{ME} / \mathrm{Kg}$ diet with $8 \% \mathrm{CGF}$ would be reasonable for feeding White Pekin ducklings from 2 to 12 weeks of age. 
Results of growth performance are in agreement with those obtained by Fan et al. (2008) who recorded that, as dietary energy increased from 2600 to $3100 \mathrm{Kcal}$ of $\mathrm{ME} / \mathrm{Kg}$ diet, the weight gain of ducks significantly increased, while the feed intake and feed/gain ratio significantly decreased and similar supporting results using broilers were reported by Dozier et al. (2007) and Ghaffari et al. (2007).

The present results of growth performance as affected by dietary CGF level are in agreement with those reported by Hillman et al. (1973) they found that, the performance of breeder turkeys was improved when CGF was included at $7.5 \%$ of the diet. Whereas, Salama (2002) concluded that the performance of broiler chicks was not significantly affected when CGF was incorporated up to $6 \%$ in the diets. Owings et al., (1988) reported that CGF can be included, on a nutritional basis, up to $10 \%$ of the diet without negatively influencing growth performance of turkey.

\section{Some carcass traits:}

Effect of energy level:

Data in Table 5 showed that liver, heart, giblets and abdominal fat percentages of White Pekin ducklings at 12 weeks of age were significantly $(\mathrm{P}<0.05)$ affected by dietary energy level. The previous carcass traits increased with increasing dietary energy level. However, no significant effects of dietary energy level on gizzard, carcass and dressing weight percentages of Pekin ducklings were observed. Similar results were obtained by Fan et al. (2008) who found that high dietary energy had no significant effect on breast and leg meat, but abdominal fat increased $(\mathrm{P}<0.05)$ when dietary $\mathrm{ME}$ was above $2700 \mathrm{Kcal} / \mathrm{Kg}$ diet in White Pekin ducklings. Also, some researchers observed no significant effects of high energy diets on breast meat yield of broilers (Yalcin et al., 1998 and Dozier et al., 2006), but increasing dietary energy might cause deposition of excess abdominal or carcass fat in broiler (Summers et al., 1992, Leeson et al., 1996 and Ghaffari et al., 2007). The increase in abdominal fat percentages with increasing dietary energy level may be due to the use of iso-protein diets in the present study which may increase the dietary $\mathrm{ME} / \mathrm{CP}$ ratio and this change may caused excess abdominal fat in ducks. The previous explanation is supported by results of Scott et al. (1959). Furthermore, more fat deposition caused by high-energy diets may be due to higher efficiency of energy retention at this instance, similar results in broilers were reported by Jackson et al.(1982) and Furuse et al. (1985). Moreover, Boekholt et al. (1994) found that the efficiency of energy retention 
was higher in fat than in protein when high energy diets were consumed by broilers.

\section{Effect of corn gluten feed:}

Results presented in Table 5 showed that liver, heart, carcass and dressing percentages were significantly $(\mathrm{P}<0.05)$ affected when $\mathrm{CGF}$ was incorporated in the diets of Pekin ducklings. However, gizzard, giblets and abdominal fat did not show any significant effect due to incorporation of CGF in the diets. It is worth to note that, liver, heart, carcass and dressing percentages were significantly $(\mathrm{P}<0.05)$ increased by the increasing dietary CGF from 0 to $16 \%$. In this respect, Salama, (2002) found that carcass, dressing, giblets and abdominal fat was not significantly affected when CGF was incorporated in broilers diet up to $6 \%$. Owings et al. (1988) reported that dietary levels of CGF, whether fed from dayold or at 9 weeks of age did not significantly affected yield of carcass parts or composition of turkeys. The same authors demonstrated that CGF can be successfully used on a nutritional basis to constitute up to $10 \%$ in growing turkey diet without negative effects on growth performance and carcass aspects.

\section{Interaction effects:}

Interaction between dietary energy levels and CGF levels were significant $(\mathrm{P}<0.05)$ on liver, heart and giblets percentages. The highest values of these parts were observed for ducklings given $3200 \mathrm{Kcal} \mathrm{ME} / \mathrm{Kg}$ diet without CGF in the diet and the lowest values of forementioned traits were obtained for ducklings given $2800 \mathrm{Kcal} \mathrm{ME} / \mathrm{Kg}$ diet with $16 \% \mathrm{CGF}$ (Table 5).

\section{Some blood serum constituents:}

Effect of energy level:

Results in Table 6 showed that the dietary energy level had significant $(\mathrm{P}<0.05)$ effect on cholesterol, AST and total protein of blood serum of White Pekin ducklings at 12 weeks of age. The increase in dietary energy level in ducklings diet was accompanied with an increase in both AST and total protein values which indicated an increase in liver function and confirmed that there was a damage in hepatic cells due to high energy levels. Similar results with broilers were obtained by Shehata (1995) and El-Hindawy et al. (1998).

Moreover, data in Table 6 indicated that increasing the dietary energy level from 2800 to either 3000 or $3200 \mathrm{Kcal} \mathrm{ME} / \mathrm{Kg}$ diet caused a significant $(\mathrm{P}<0.05)$ increase in cholesterol values. Also, values of triglycerides increased with increasing dietary energy level, but the differences due to energy level effect in 
duckling diets were not significant. Nearly results were obtained by Shehata (1995) and El-Hindawy et al. (1997) with broiler chicks. The found that chicks fed high dietary energy level caused a significant increase in total lipids.

\section{Effect of corn gluten feed:}

Results of blood serum constituents studied of ducklings fed CGF at 12 weeks of age are presented in Table 6 . The components of blood serum indicated that serum AST was significantly $(\mathrm{P}<0.05)$ increased and total protein decreased with increasing CGF levels up to $16 \%$. Whereas, ALT, albumin and globulin contents were not significantly affected by CGF level in duckling diets.

It is worth to note that cholesterol content was significantly $(\mathrm{P}<0.05)$ decreased with increasing the dietary CGF levels. This may be due to that CGF contains cholesterol suppressive agents and that the mechanism of their hypocholesterollemic action is at the level of suppression of cholesterol biosynthesis. Also, increasing the dietary CGF level from 0 to either 8 or $16 \%$ caused a significant $(\mathrm{P}<0.05)$ decrease in triglycerides contents (Table 6).

\section{Interaction effects:}

The interaction effects due to dietary energy and CGF levels were significant $(\mathrm{P}<0.05)$ on all serum blood constituents studied (triglycerides, cholesterol, AST, ALT, total protein, albumin and globulin), except albumin content (Table 6).

\section{Economical efficiency:}

Data presented in Table 7 showed that ducklings fed the diet contained $3000 \mathrm{Kcal} \mathrm{ME} / \mathrm{Kg}$ diet recorded the best economical efficiency (EEf) value as compared with other energy levels.

It is clear that duckling fed on the diet contained 8\% CGF had better EEf value as compared with the other treatment or the control (Table 7).

The best results of EEf values were recorded by ducklings fed $3000 \mathrm{Kcal}$ $\mathrm{ME} / \mathrm{Kg}$ diet with $8 \% \mathrm{CGF}$ up to 12 weeks of age.

Conclusively, from the nutritional and economical point of view it can be concluded that a dietary level of $3000 \mathrm{Kcal} \mathrm{ME} / \mathrm{Kg}$ with $8 \% \mathrm{CGF}$ is recommended for feeding of growing White Pekin ducklings from 2-12 weeks of age, under Egyptian environmental conditions. 


\section{REFERENCES}

Boekholt, H. A.; Van Der Grinten, P. H.; Schreurs, V. V.; Los, M. J. and Leffering, C. P. (1994). Effect of dietary energy restriction on retention of protein, fat and energy in broiler chicks. Br. Poult. Science, 35:603-614.

Coles, E. H. (1974). Veterinary Clinical Pathology. PP. 211-213, W.B. Saunders, and other antibiotics. Poultry Science, 42: 681- 685.

Dozier, W. A.; Corzo, I. A.; Kidd, M. T. and Branton, S. L. (2007). Dietary apparent metabolizable energy and amino acid density effects on growth and carcass traits of heavy broilers. J. of Applied Poultry Research, 16:192-205.

Dozier, W. A.; Price, I. C. J.; Kidd, M. T.; Corzo, A.; Anderson, J. and Branton, S. L. (2006). Growth performance, meat yield, and economic responses of broilers fed diets varying in metabolizable energy from thirty to fifty-nine days of age. Journal of Applied Poultry Research, 15:367-382.

Duncan, D. B. (1955). The Multiple Range and multiple F-Tests. Biometrics, 11: 1-42.

El-Deek, A. A.; Mona Osman and Mona Mahmoud (2009). Effect of dietary corn gluten feed and phytase supplementation to laying hens diets. Egyptian Poultry Science, 1:21-28.

El-Hindawy, M. M.; Tawfeek, M. S. and Omar, A. M. (1997). Growth performance of broiler chicks as affected by dietary energy levels and biological feed additives supplementation. International Conference on Animal, Poultry, Rabbit Production and Health, Egypt, 401-414.

Emam, R. M. S. (2007). Productive performance of Japanese quail as affected by feeding on some medicinal and aromatic plants and their by-products with or without enzymes supplementation. M. Sc. Thesis, Faculty of Agriculture, Fayoum University, Egypt.

Fan, H. P.; Xie, M.; Wang, W. W.; Hou, S. S. and Huang, W. (2008). Effects of dietary energy on growth performance and carcass quality of White growing Pekin ducks from two to six weeks age. Poultry Science, 87:1162-1164.

Furuse, M.; Yokota, H. and Tasaki, I. (1985). Influence of energy intake on growth and utilization of dietary protein and energy in germ-free and conventional chicks. Br. Poultry Science, 26:389-397.

Ghaffari, M.; Shivazad, M.; Zaghari, M. and Taherkhani, R. (2007). Effects of different levels of metabolizable energy and formulation of diet based on digestible and total amino acid requirements on performance of male broiler. Int. Journal of Poultry Science, 6:276-279. 
Henry. R. F. (1974). "Clinical Chemistry Principles and Techniques" $2^{\text {nd }}$ Ed., Harper and Row, Hager stein, MD.

Hillman, R.I.; Kienholz, E. W. and Shroder, T. (1973). The effect of corn gluten feed in chicken and turkey breeder diets. Poultry Science, 52:2309 (Abst.).

Jackson, S.; Summers, J. D. and Leeson, S. (1982). Effect of dietary protein and energy on broiler carcass composition and efficiency of nutrient utilization. Poultry Science, 61:2224-2231.

Leeson, S.; Caston, L. and Summers, J. D. (1996). Broiler response to dietary energy. Poultry Science, 75:529-535.

NRC, (1994). National Research Council. Nutrient Requirements of Poultry. $9^{\text {th }} \mathrm{Ed}$, National Academic of Science. Washington, DC. USA.

Owings, W. J.; Sell, L.; Ferket, P. and Hasiak, R. J. (1988). Growth performance and carcass composition of turkey hens fed corn gluten feed. Poultry Science, 67:585-589.

Reinhold, J.G. (1953). Standard of Clinical Chemistry. M. Reinc. (Ed): P: 88, Academic Press New York.

Salama, I. A. (2002). A study on broiler chicks feeds and feeding. M. Sc. Thesis. Fac. of Agriculture, Zagazig University, Egypt.

SAS Institute, (1999). SAS User's Guide. Release 8.2 Ed. SAS Ins. Inc. Cary. NC.

Scott, M. L.; Hill, F. W.;. Parsons, E. H; Bruckner, J. H. and Dougherty, E. (1959). Studies on duck nutrition. 7. Effect of dietary energy: Protein relationships upon growth, feed utilization and carcass composition in market ducklings. Poultry Science, 38:497-507.

Shehata, A. S. A. (1995). Productive performance of growing broiler chicks as affected by energy protein ratio and methionine levels. Ph. D. Thesis, Fac. of Agric., Zagazig University, Zagazig, Egypt.

Summers, J. D.; Spratt, D.and Atkinson, J. L. (1992). Broiler weight gain and carcass composition when fed diets varying in amino acid balance, dietary energy and protein level. Poultry Science, 71:263-273.

Yalcin, S.; Zkan, S.O.; Acikgoz, Z. and Zkan, K. (1998). Influence of dietary energy on bird performance, carcass parts yields and nutrient composition of breast meat of heterozygous naked neck broilers reared at natural optimum and summer temperatures. Br. Poultry Science, 39:633-638. 
تأثير طاقة الغذاء والجلوتوفيد علي أداء البط البكيني الأبيض النامي.

$$
\text { إبراهيم إبراهيم حسن الإنتاج الحيوانيـ مركز البحوث الزر اعية ـ الدقي ـ الجيزة - مصر }
$$

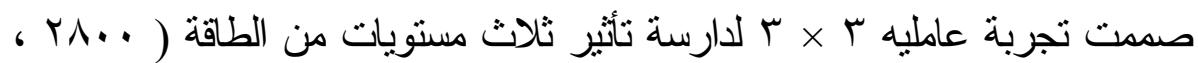

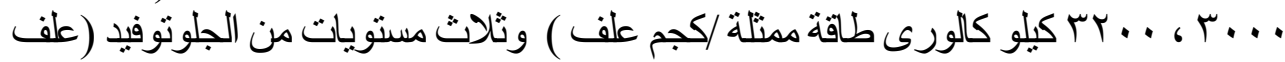

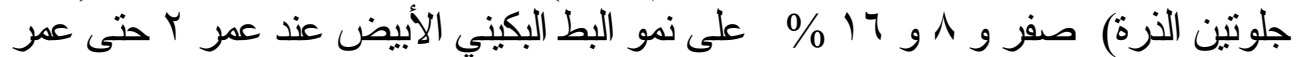

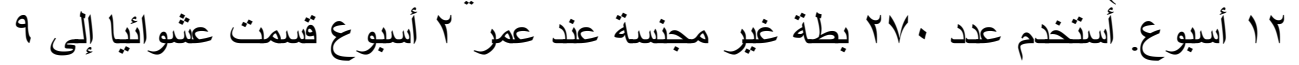

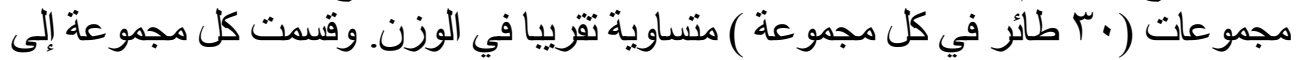

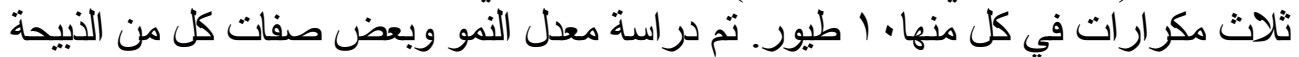
و والدم وكنلك الكفاءة الاقتصادية.

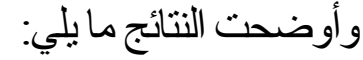

زاد منوسطوزن الجسم وكنلك و الزيادة في وزن الجسم معنويا (P<0.05) مع العليقة

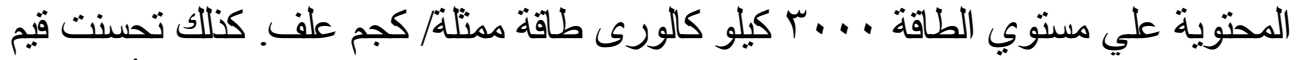

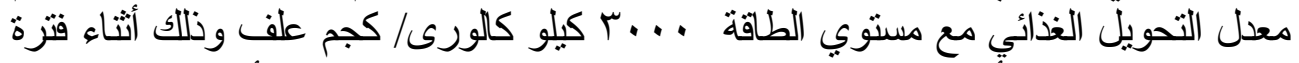

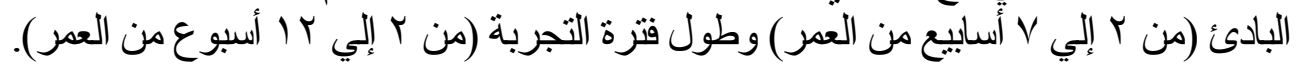

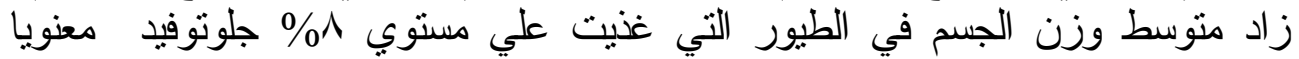
(P<0.05)

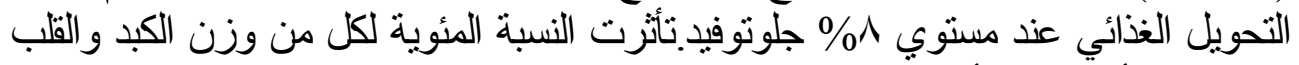

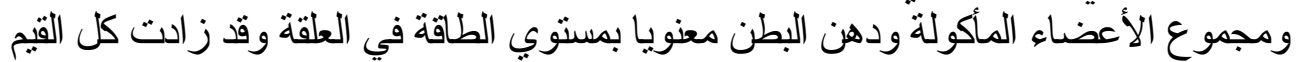

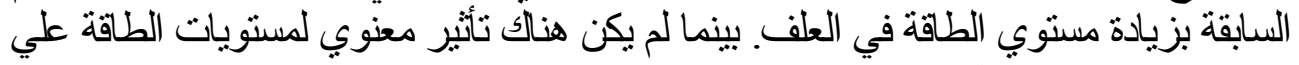

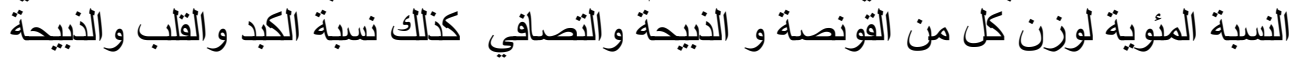

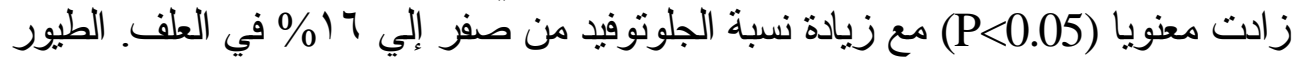

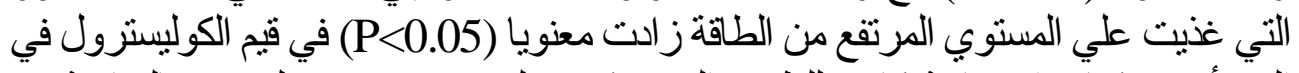

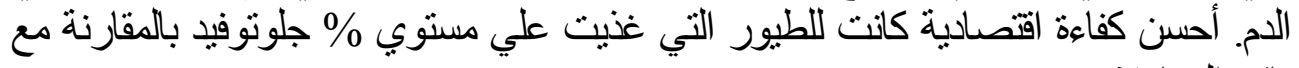

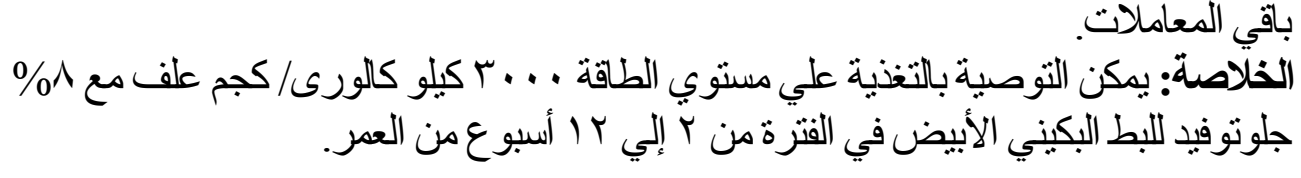

